\title{
Effect of animal waste and vegetable compost on production and growth of earthworm (Eisenia fetida) during vermiculture
}

\author{
D. S. J. V. Vodounnou ${ }^{1}$ • D. N. S. Kpogue ${ }^{2}$ C. E. Tossavi ${ }^{1}$ - G. A. Mennsah ${ }^{3}$ • \\ E. D. Fiogbe ${ }^{1}$
}

Received: 16 July 2015/ Accepted: 30 January 2016/Published online: 20 February 2016

(c) The Author(s) 2016. This article is published with open access at Springerlink.com

\begin{abstract}
Purpose The purpose of the study is to evaluate the effect of different animal product wastes and plant compost on survival and growth of earthworm (Eisenia fetida).

Methods The study is realized in a vermibin for a duration of 90 days. The initial physico-chemical parameters ( $\mathrm{pH}$, humidity, ash, organic matter, carbon, nitrogen, phosphorus and $\mathrm{C}: \mathrm{N}$ ratio) were determined in each waste of the different substrates before the study. Six waste products (pig, poultry, rabbit, cattle, sheep and vegetal compost $)$ in triplicate $(6 \times 3)$ were used for earthworm production. In each 12-1 content vermibin, $2 \mathrm{~kg}$ of substrate and $30 \mathrm{~g}$ of mature earthworms were sown. Each month, the growth control was realized by earthworms harvest and weighing. The earthworms were put back in substrate in vermibin and $500 \mathrm{~g}$ of substrate were completed. The $\mathrm{pH}$ was measured every week.

Results The physico-chemical parameters $(\mathrm{pH}$, ash, organic matter, carbon, phosphorus, nitrogen and $\mathrm{C}: \mathrm{N}$ ratio) varied $(P<0.05)$ according to different substrate. The C:N ratio of different organic substrates are in the range of 8.46 in vegetable compost to 19.39 in pig dung. At the end of study the biomass gain and mortality varied
\end{abstract}

D. S. J. V. Vodounnou

justeking@yahoo.fr

1 University of Abomey-Calavi (UAC), Faculty of Science and Techniques (FAST), Laboratory of Research in the Wetlands (LRZH), 01 BP 526, Cotonou, Benin

2 Agricultural University of Ketou (UAK), BP 43, Kétou, Benin

3 Benin National Agricultural Research Institute (INRAB), Cotonou, Benin
$(P<0.05)$ according to different treatments. The growth rate varied according to different organic waste $(P<0.05)$ and ranged between $-0.06 \pm 0.02$ (vegetable compost) and $1.34 \pm 0.11$ (cow dung). Maximum weight gain and highest growth rate were attained with cow dung. Earthworm biomass gain in different animal wastes is in the order of: cow $>$ pig $>$ rabbit $>$ poultry $>$ sheep $>$ compost vegetable.

Conclusion The animal wastes (cow, sheep, pig, rabbit and poultry) and vegetable compost can be used to produce the earthworm. But the growth and produce depend on the biochemical quality of the substrates and the availability and facility for using a nutritive element.

Keywords Eisenia fetida · Growth · Animal waste . Vegetable compost · Production · Vermicompost

\section{Introduction}

According to growing trend of using chemical fertilizers in agriculture and its associated environmental impacts specially in developing countries, application of management strategies are necessary to reduce its effects. Nonfundamental and long-term consumption of fertilizers not only lead to degradation of soil quality, but also can reduce product quality, that disrupt the natural balance of the ecosystems and increases the environmental pollution. In the past half century, using chemical fertilizers significantly has increased yield of the agriculture products. The environmental stability results from the use of fertilizers, on one hand and on the other hand, will face problems food production in the coming decade (Tohidinejad et al. 2011). The vermiculture as means of reducing the greenhouse gas emissions that have negative impacts on the environment, 
although waste sector produces the least quantity of greenhouse gases (Roghaye 2012).

The management of organic waste, in the circumstance the animals dung in the farms represented a serious problem in Benin. However, a good management of this organic waste can contribute a supply an animal protein for aquaculture and organic fertilizer for market garden produce. Vermicomposting technology is neither developed and nor practiced in Benin; whereas, this technology constitutes one of the tools for management an organic waste (Manyuchi and Nyamunokora 2014; Manyuchi et al. 2014; Manyuchi and Phiri 2013). It has been described as a biological process for converting solid waste into a stable, humus-like product, which is used as a soil conditioner (Talashilkar 1989). The vermicompost has many advantages: obtaining the earthworms biomass which one can valorize through the feed of the animals, especially in aquaculture (Roghaye 2012) and is biological manure very much used in vegetable production, for example into product the tomato and peppermint (Zucco et al. 2015; Ayyobi et al. 2014). The earthworms are used through the waste recycling organics urban, industrial and agricultural (Reinecke et al. 1992). Indeed, $1 \mathrm{~kg}$ of adults earthworm can convert up to $5 \mathrm{~kg}$ of waste per day and approximately $10 \mathrm{~kg}$ of adults can convert one ton waste per month (Mahmoud 2011). Many species could be used for these utilities. Eisenia fetida is the species who support the tropical climatic conditions. This species can reproduce normally at a temperature ranging between $\left(20\right.$ and $25^{\circ} \mathrm{C}$ ) and can tolerate a temperature upto $29^{\circ} \mathrm{C}$ (Tomlin 1981; Lee 1985; Curry 1998). It is an epigeic earthworm living on the upper surface of soils feeding mainly on plant litter and other organic debris available on the soil surface. As these earthworms can consume a variety of organic matter, they are most suitable for converting organic wastes into useful organic manures (Chattopadhyay 2012). This species can be used for composting Azolla pinnata (Ishtiyaq and Anisa 2010), paper mill (Karn and Chakrabarti 2015) and for composting municipal solid wastes (Mishra et al. 2014). In Benin farms, the animals bred are often pig, poultry, rabbit, cattle, and sheep. The management of these wastes constitutes a problem in the farms. However, these wastes could be of value for vermicomposting. But the diet of these animals differs, which induced a difference of chemical quality of their waste. The aim of this study is to promote in Benin the vermicomposting in the farms with various animal wastes and to evaluate the impact of these various animal wastes (pig, poultry, rabbit, cattle, and sheep) on the earthworm biomass production. Moreover, the impact of the vegetable compost on the production of these earthworms will be also evaluated.

\section{Materials and methods}

\section{Collection of earthworms}

Adults of E. fetida (clitellum accented) were collected from lots of garbage in Benin National Agricultural Research Institute (INRAB) and grown in laboratory of research in the wetlands (LRZH) of Abomey-Calavi University.

\section{Collection and preparation of organic substrates}

Fresh waste of different animals (pig, poultry, rabbit, cattle, and sheep) was collected from animal farms in AbomeyCalavi. The animal dung was used 14 days after the collection, because pre-composting is very essential to avoid the death of the worm (Gunadi and Edwards 2003). The plant compost obtained of the Abomey-Calavi University was used for our experimentation.

$\mathrm{pH}$ was determined using $\mathrm{pH}$ paper introduced in the wet substrate. Total carbon was measured using the method of Nelson and Sommers (1982). Organic matter was determined by $\mathrm{MO} \%=\mathrm{C} \% \times 1.724$. Nitrogen was determined according to Bremner and Mulvaney (1982). Total phosphorus was analyzed using the colorimetric method with molybdenum in sulphuric acid.

\section{Culture of earthworms and growth studies}

Six waste products (pig, poultry, rabbit, cattle, sheep and vegetal compost) in triplicate $(6 \times 3)$ were used for earthworm production. In each 12-1 content vermibin, $2 \mathrm{~kg}$ of substrate and $30 \mathrm{~g}$ of mature earthworms were sown. Each month, the growth control was realized by earthworms harvest and weighing. The earthworms were put back in substrate in vermibin and $500 \mathrm{~g}$ of substrate were completed. The $\mathrm{pH}$ has been measured every week.

\section{Zootechnical parameters and statistical analysis}

\section{Zootechnical parameters}

$\mathrm{GR}=\frac{\mathrm{Wf}-\mathrm{Wi}}{t 2-t 1} P=\frac{\mathrm{Wf}-\mathrm{Wi}}{Q}$

with: $W i$ initial weight of the worms, $W f$ final weight of the worms, $t 1$ start of the experiment (in days), $t 2$ end of the experiment (in days), $Q$ total waste (in $\mathrm{kg}$ ), $\mathrm{Ni}$ initial number, $N f$ final number, $P$ produce (g/earthworm/kg of waste), GR growth rate (mg/worm/day), WMI initial weight mean, $W M F$ final weight mean 


\section{Statistical analysis}

Treatment effect was evaluated using one-way analysis of variance (ANOVA) with StatView software after verifying the homogeneity of variance using "Hartley's test" for each experiment. Significant differences between treatments means $(P<0.05)$ were determined using a Fisher's least-significant difference test (Saville 1990). Results are given as mean $\pm \mathrm{SE}$.

\section{Results}

\section{Physico-chemical parameters of the substrates}

The initial physico-chemical parameters of the different substrates before use are summarized in the Table 1. The $\mathrm{pH}$ values of the organic substrates ranged between 5.88 (poultry) and 8.52 (cow). The moisture content of the organic substrate before use varied between $3.43 \%$ and $12.66 \%$. The ash varied between $31.48 \%$ and $84.4 \%$ (Table 1). The carbons of different organic substrates are in the range of $9.05 \%$ in vegetable compost to $37.34 \%$ in rabbit dung. The nitrogen ranged from $1.07 \%$ in vegetable compost to $2.56 \%$ in sheep dung. The C:N ratio of different organic substrates are in the range of 8.46 in vegetable compost to 19.39 in pig dung. Phosphorus content ranged from $0.06 \%$ in vegetable compost to $1.04 \%$ in rabbit waste.

\section{Survival, growth performance, and organic substrate utilization by earthworm}

\section{Earthworms survival rate}

During the study, no mortality was observed in cow, pig and rabbit dung. But in poultry, sheep dung and vegetable compost, the mortalities were observed. In vegetable compost the mortality was observed in the whole study period.

\section{Growth performance and organic substrate utilization by earthworm}

The different parameters of growth performance and organic substrate utilization by earthworm are given in Table 2.

The growth rate varied according to different organic waste $(P<0.05)$. These values ranged between $-0.06 \pm$ 0.02 (vegetable compost) and $1.34 \pm 0.11$ (cow dung).

In the first week, the growth was slow, the growth rate steadily increased thereafter and it reached its maximum during the 90th day, excepted vegetable compost where the growth has decreased (Fig. 1).

Table 1 Initial physico-chemical parameters of the organic substrates

\begin{tabular}{lllllllll}
\hline Organic substrates & $\mathrm{pH}$ & $\begin{array}{l}\text { Moisture content } \\
\%\end{array}$ & Ash \% & $\begin{array}{l}\text { Organic matter } \\
\%\end{array}$ & $\begin{array}{l}\text { Phosphorus } \\
(\mathrm{P}) \%\end{array}$ & $\begin{array}{l}\text { Carbon } \\
(\mathrm{C}) \%\end{array}$ & $\begin{array}{l}\text { Nitrogen } \\
(\mathrm{N}) \%\end{array}$ & $\begin{array}{l}\text { Ratio } \\
\mathrm{C}: \mathrm{N}\end{array}$ \\
\hline Rabbit & 8.16 & 12.66 & 35.62 & 64.38 & 1.04 & 37.34 & 2.46 & 15.18 \\
sheep & 8.32 & 11.76 & 39.55 & 60.45 & 0.59 & 35.06 & 2.99 & 11.73 \\
cow & 8.52 & 8.71 & 60.24 & 39.76 & 0.37 & 23.06 & 2.06 & 11.19 \\
Pig & 7.94 & 10.29 & 31.48 & 68.52 & 0.42 & 39.74 & 2.05 \\
Poultry & 5.88 & 6.84 & 63.27 & 36.73 & 0.6 & 21.31 & 1.82 & 11.71 \\
Vegetable compost & 6.84 & 3.43 & 84.4 & 15.6 & 0.06 & 9.05 & 1.07 \\
\hline
\end{tabular}

Table 2 Growth performance, and organic substrate utilization

\begin{tabular}{llccccc}
\hline Parameters & Poultry & \multicolumn{1}{l}{ Rabbit } & Sheep & Cow & Pig & Compost \\
\hline WI & $30.00 \pm 0.00^{\mathrm{a}}$ & $30.00 \pm 0.00^{\mathrm{a}}$ & $30.00 \pm 0.00^{\mathrm{a}}$ & $30.00 \pm 0.00^{\mathrm{a}}$ & $30.00 \pm 0.00^{\mathrm{a}}$ & $30.00 \pm 0.00^{\mathrm{a}}$ \\
NI & $20.00 \pm 0.00^{\mathrm{a}}$ & $20.00 \pm 0.00^{\mathrm{a}}$ & $20.00 \pm 0.57^{\mathrm{a}}$ & $20.00 \pm 1.15^{\mathrm{a}}$ & $20.00 \pm 0.00^{\mathrm{a}}$ & $20.00 \pm 0.00^{\mathrm{a}}$ \\
WF & $64.66 \pm 6.74^{\mathrm{a}}$ & $90.33 \pm 14.49^{\mathrm{b}}$ & $35.00 \pm 5.13^{\mathrm{c}}$ & $151.00 \pm 9.71^{\mathrm{d}}$ & $135.33 \pm 8.11^{\mathrm{e}}$ & $24.33 \pm 2.33^{\mathrm{f}}$ \\
NF & $88.00 \pm 6.92^{\mathrm{a}}$ & $203.00 \pm 75.10^{\mathrm{b}}$ & $98.0 \pm 13.56^{\mathrm{c}}$ & $281.00 \pm 29.56^{\mathrm{d}}$ & $350.00 \pm 26.34^{\mathrm{e}}$ & $48.00 \pm 3.48^{\mathrm{f}}$ \\
WMI & $1.50 \pm 0.00^{\mathrm{a}}$ & $1.50 \pm 0.04^{\mathrm{a}}$ & $1.50 \pm 0.04^{\mathrm{a}}$ & $1.50 \pm 0.09^{\mathrm{a}}$ & $1.50 \pm 0.00^{\mathrm{a}}$ & $1.50 \pm 0.00^{\mathrm{a}}$ \\
WMF & $0.73 \pm 0.02^{\mathrm{a}}$ & $0.44 \pm 0.08^{\mathrm{b}}$ & $0.35 \pm 0.01^{\mathrm{c}}$ & $0.53 \pm 0.04^{\mathrm{d}}$ & $0.38 \pm 0.03^{\mathrm{e}}$ & $0.50 \pm 0.01^{\mathrm{f}}$ \\
GR & $0.38 \pm 0.07^{\mathrm{a}}$ & $0.67 \pm 0.16^{\mathrm{b}}$ & $0.05 \pm 0.05^{\mathrm{c}}$ & $1.34 \pm 0.11^{\mathrm{d}}$ & $117 \pm 0.09^{\mathrm{e}}$ & $-0.06 \pm 0.02^{\mathrm{f}}$ \\
P & $11.55 \pm 2.24^{\mathrm{a}}$ & $20.11 \pm 4.83^{\mathrm{b}}$ & $1.66 \pm 1.71^{\mathrm{c}}$ & $40.33 \pm 3.23^{\mathrm{d}}$ & $35.11 \pm 2.70^{\mathrm{e}}$ & $-1.89 \pm 0.77^{\mathrm{f}}$ \\
\hline
\end{tabular}

Each value is mean \pm SE of triplicates. Means on the same line followed by different superscripts are significantly different $(P<0.05)$ 


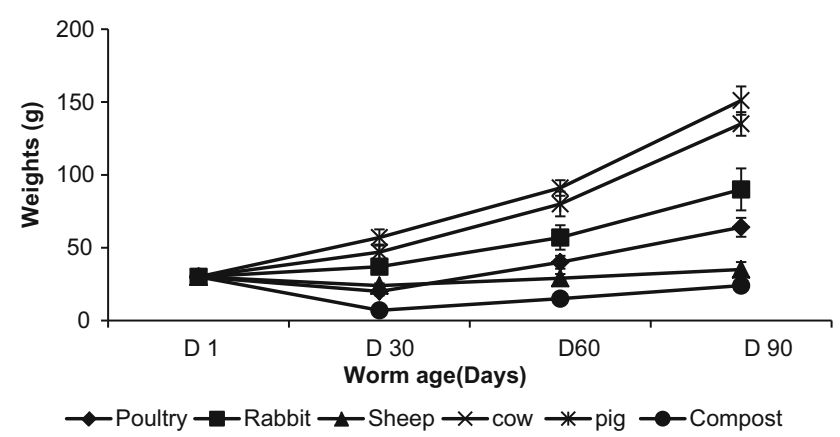

Fig. 1 Growth curves for earthworms (Eisenia fetida) in various organic substrates over a period of study (90 days)

The growth rate for E. fetida per gram, per worm and per day $(\mathrm{g} / \mathrm{worm} /$ day $)$ is: cow dung $(1.34 \pm 0.11)>$ pig dung $(1.17 \pm 0.09)>$ rabbit dung $(0.67 \pm 0.16)>$ poultry dung $(0.38 \pm 0.07)>$ sheep dung $(0.05 \pm 0.05)>$ vegetable compost $(-1.89 \pm 0.77)$ (Fig. 2).
The produce (worm $\mathrm{g} / \mathrm{kg}$ substrate) was higher in cow dung (40. $33 \pm 3.23)$ and negative in compost vegetable $(-1.89 \pm 0.77)$ (Fig. 3).

\section{Discussion}

\section{Physico-chemical parameters of the substrates}

The $\mathrm{pH}$ values of the organic substrates are alkaline for rabbit, sheep, cow and pig, ranging between 7.94 and 8.52 . But the $\mathrm{pH}$ values of poultry (5. 88) and plant compost (6.84) are acids. This acidity can be proved by the large in nitrogen and mineral in poultry manure (Sherman 2003). The ash varied between $31.48 \%$ (pig) and $84.4 \%$ (vegetable compost). These values are relatively high because the organic substrates used contained sand, particularly the vegetable compost with $84.4 \%$. The carbon in cow dung is higher compared to the carbon in cow dung used by Bisht
Fig. 2 Growth rate of Eisenia fetida on different organic substrates

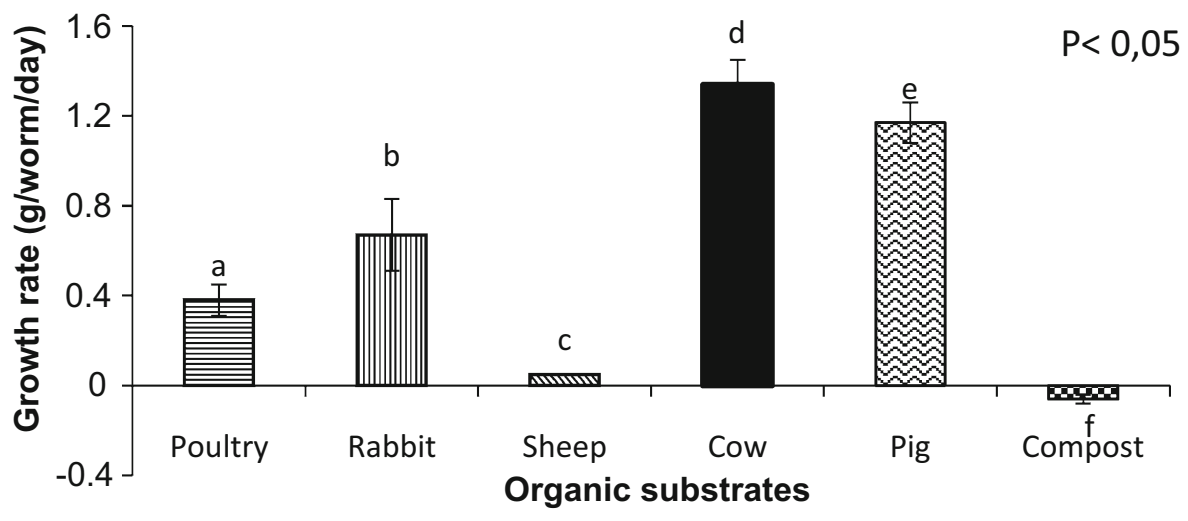

Poultry $\mathbf{m}$ Rabbit $\mathbb{Q}$ Sheep Cow $⿴ 囗 ⿱ 一 一)$ Pig $\mathbf{0}$ Compost
Fig. 3 Produce of Eisenia fetida on different organic substrates

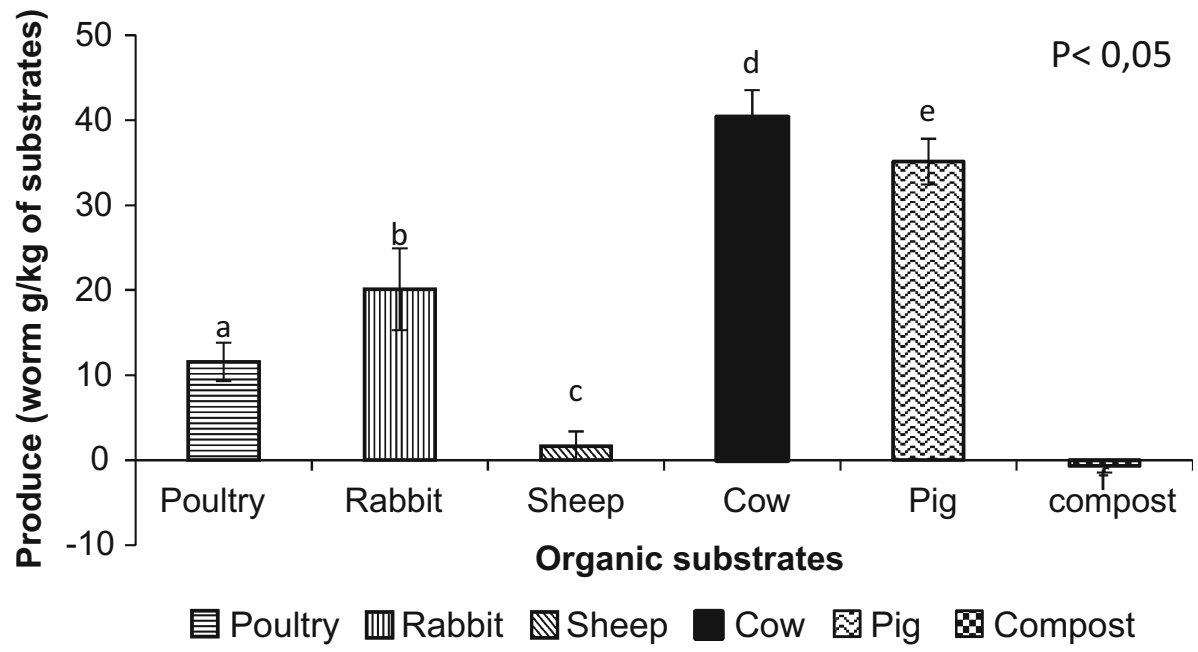


et al. (2007) to evaluate the reproductive potential of the earthworms (Metaphire posthuma). The nitrogen ranged from $1.07 \%$ in vegetable compost to $2.56 \%$ in sheep dung. The C:N ratio of different organic substrates are in the range of 8.46 in vegetable compost to 19.39 in pig dung. The C:N ratio in cow dung is low compared to $\mathrm{C}: \mathrm{N}$ ratio in cow dung used by Garg et al. (2005) to produce earthworms.

\section{Survival, growth performance, and organic substrate utilization by earthworm}

During the study, no mortality was observed in cow pig and rabbit dung. But in poultry, sheep dung and vegetable compost, mortalities were observed. The mortality in poultry dung was observed only in the first month of the study. The mortality in poultry might be due to the higher nitrogen and mineral content (Sherman 2003). It can be proved by the anaerobic conditions which developed (Garg et al. 2005). In vegetable compost the mortality is observed in the whole study period. The mortality observed in vegetable compost is due to high sand (ash: $84.4 \%$ ) contained in the vegetable compost.

Production depends on the biochemical quality of the feeds. Feeds which provide earthworms with sufficient amount of easily metabolizable organic matter and non-assimilated carbohydrates, favor growth and reproduction of earthworms (Edwards 1988). The growth rate varied according to different organic waste $(P<0.05)$. These values ranged between $-0.06 \pm 0.02$ (vegetable compost) and $1.34 \pm 0.11$ (cow dung). This variation can be proved by the palatability, the type and the quality of different substrates (Tripathi and Bhardwaj 2004; Gajalakshmi et al. 2005).

In the first week, the growth was slow, the growth rate steadily increased thereafter and it reached its maximum during the 90th day, except in vegetable compost where the growth has decreased. The growth rate for E. fetida per gram, per worm and per day (g/worm/day) is: cow dung $(1.34 \pm 0.11)>$ pig dung $(1.17 \pm 0.09)>$ rabbit dung $(0.67 \pm 0.16)>$ poultry dung $(0.38 \pm 0.07)>$ sheep dung $(0.05 \pm 0.05)>$ vegetable compost $(-1.89 \pm 0.77)$. Several results have proved the use of cow dung in vermicomposting. Our results corroborate according to the use of cow dung in vermicomposting with the findings of Bhat et al. 2015 where the cow dung is mixed with the bagasse. But our results are different from that observed by Garg et al. (2005), where the sheep dung results are the highest compared to the cow dung. This difference is due to the biomass gain by $E$. fetida which are dependent on population density and food type (Neuhauser et al. 1980). In this study, earthworm biomass increased in all animal waste. Our results corroborate with the findings of Rathinamala et al. (2008) who reported increase in body weight of
Eisenia fetida and Eudrilus eugeniae feeding on different organic waste. This increase in organic waste can be proved also by presence of fungi during vermicomposting. Indeed, Pramanik and Chung (2011) have reported that the fungi in vermicomposting become additional food to the worms which contribute to the higher weight of the worms.

The produce (worm $\mathrm{g} / \mathrm{kg}$ substrate) was higher in cow dung $(40.33 \pm 3.23)$ and negative in compost vegetable $(-1.89 \pm 0.77)$. The negative produce obtained is due to the high mortality observed in this substrate. However, in another experiment, the produce was $34.0 \pm 1.90 \mathrm{mg} / \mathrm{g}$ by E. fetida species in cow dung at $27{ }^{\circ} \mathrm{C}$. In horse waste, produce by $P$. excavatus species was about two times higher than E. fetida. This difference could be due to the difference in species morphology and initial characteristics of the feed waste (Edwards et al. 1998).

\section{Conclusion}

The current study proved that animal wastes (cow, sheep, pig, rabbit and poultry) and vegetable compost can be used to produce the earthworm. But the growth and produce depend on the biochemical quality of the substrates and the availability and facility for using a nutritive element. The first substrate favored by Eisenia fetida among the animal wastes in this study is the cow dung followed by pig dung.

Acknowledgments This study was supported by the Ministry of Higher Education and Scientific Research of Republic of Benin which provided a $\mathrm{PhD}$ grant to Vodounnou D.S. Juste Vital.

Authors' contributions All authors, Vodounnou, Tossavi, Kpogue, Mensah and Fiogbe have made adequate effort on all parts of the work necessary for the development of this manuscript according to his/her expertise. All authors read and approved the final manuscript.

\section{Compliance with ethical standards}

Conflict of interest The authors declare that there is no conflict of interest.

Open Access This article is distributed under the terms of the Creative Commons Attribution 4.0 International License (http://crea tivecommons.org/licenses/by/4.0/), which permits unrestricted use, distribution, and reproduction in any medium, provided you give appropriate credit to the original author(s) and the source, provide a link to the Creative Commons license, and indicate if changes were made.

\section{References}

Ayyobi H, Olfati J-A, Peyvast G-A (2014) The effects of cow manure vermicompost and municipal solid waste compost on peppermint (Mentha piperita L.) in Torbat-e-Jam and Rasht regions of Iran. Int J Recycl Org Waste Agric 3:147-153. doi:10.1007/s40093014-0077-8 
Bhat SA, Singh J, Vig AP (2015) Potential utilization of bagasse as feed material for earthworm Eisenia fetida and production of vermicompost. Int J Recycl Org Waste Agric 4(11):9p. doi:10. 1186/s40064-014-0780-y

Bisht R, Pandey H, Bharti D, Bisht SPS, Kaushal BR (2007) Reproductive potential of the earthworm Metaphire posthuma (Oligochaeta) in different food substrates. Trop Ecol 48(1):107-114

Bremner JM, Mulvaney RG (1982) Nitrogen total: method of soil analysis. Am Soc Agron, Madison, pp 575-624

Chattopadhyay GN (2012) Use of vermicomposting biotechnology for recycling organic wastes in agriculture. Int $\mathrm{J}$ Recycl Org Waste Agric 1:8. doi:10.1186/2251-7715-1-8

Curry JP (1998) Factors affecting earthworms abundance in soils. In: Edwards CA (ed) Ecology. St. Lucie press, Boca Raton, p 389

Edwards CA (1988) Breakdown of animal, vegetable and industrial organic wastes by earthworms. SPB Academic Publishing, Hague, pp 21-31

Edwards CA, Dominguez J, Neuhauser EF (1998) Growth and reproduction of Perionyx excavatus (Per.) (Megascolecidae) as factors in organic waste management. Biol Fertil Soils 27:155-161

Gajalakshmi S, Ramasamy EV, Abbasi SA (2005) Compostingvermicomposting of leaf litter ensuing from the trees of mango (Mangifera indica). Bioresour Technol 96:1057-1061

Garg VK, Chand S, Chhillar A, Yadav A (2005) Growth and reproduction of Eisenia fetida in animal wastes. Appl Ecol Environ Res 3(2):51-59

Gunadi B, Edwards CA (2003) The effect of multiple application of different organic waste on the growth, fecundity and survival of E. fetida. Pedobiologia 47(4):321-330

Ishtiyaq AN, Anisa BK (2010) Vermicomposting of invasive species azolla pinnata With Eisenia fetida. Int Qvermibinterl J Life Sci 5(2):239-241

Karn SK, Chakrabarti SK (2015) Simultaneous biodegradation of organic (chlorophenols) and inorganic compounds from secondary sludge of pulp and paper mill by Eisenia fetida. Int J Recycl Org Waste Agric 4:53-62. doi:10.1007/s40093-015-0085-3

Lee KE (1985) Earthworms: their ecology and relationship with soils and land Use. Academic press, New York, p 411

Manyuchi MM, Nyamunokora M (2014) Granulation of vermicompost using vermiwash as a binding media. Glob J Eng Sci Res $1(1): 4-6$

Manyuchi MM, Phiri A (2013) Vermicomposting as a solid waste management strategy: a review. Int J Sci Eng Technol 2(12): $1234-1242$

Manyuchi MM, Mudamburi T, Phiri A, Muredzi P, Kanhukamwe QC (2014) Impact of vermicompost on peas cultivated soil. Glob J Eng Sci Res 1(1):1-3
Mishra K, Singh K, Tripathi CPM (2014) Management of municipal solid wastes and production of liquid biofertilizer through vermic activity of epigeic earthworm Eisenia fetida. Int J Recycl Org Waste Agric 3:56. doi:10.1007/s40093-014-0056-0

Nelson DW, Sommers LE (1982) Total carbon and organic carbon and organic matter: method of soil analysis. Am Soc Agron, Madison, pp 539-579

Neuhauser EF, Hartenstein R, Kaplan DL (1980) Growth of the earthworm Eisenia fetida in relation to population density and food rationing. Oikos 35:93-98

Pramanik P, Chung YR (2011) Changes in fungal population of fly ash and vinasse mixture during vermicomposting by Eudrilus eugeniae and Eisenia fetida, documentation of cellulose isozymes in vermicompost. Waste Manage 31:1169-1175

Rathinamala J, Jayashree S, Lakshmanaperumalsamy P (2008) Potential utilization of domestic wastes as a suitable experimental diet to enhance the biomass of Eudrilus eugeniae in various seasons. Ecol Environ Conserv 14:43-50

Reinecke AJ, Viljoen SA, Saayman RJ (1992) The suitability of Eudrilus eugeniae, Perionyx excavatus and Eisenia fetida (Oligochaeta) for vermicomposting in Southern Africa in terms of their temperature requirements. Soil Biol Biochem 24:1295-1307

Roghaye F (2012) A review on earthworm Esienia fetida and its applications. Ann Biol Res 3(5):2500-2506

Saville DJ (1990) Multiple comparison procedures: the practical solution. Am Stat 44(2):174-180

Sherman R (2003) Raising earthworms successfully. North Carolina Cooperative Extension Service, Raleigh

Talashilkar SC (1989) Recycling of urban wastes in agriculture. In: Mishara PC (ed) Soil pollution and soil organism. Ashish Publ, House, New Delhi, pp 177-208

Tohidinejad E, Madani H, Jenabi M (2011) Organic fertilizers and vermicompost. Shahid Bahonar university of Kerman publications, Kerman, p 150

Tomlin AD (1981) Elevage des vers de terre, no. 489. Agriculture Canada. Canadex, p 4

Tripathi G, Bhardwaj P (2004) Comparative studies on biomass production, life cycles and composting efficiency of Eisenia fetida (Savigny) and Lampito mauritii (Kinberg). Bioresour Technol 92:275-278. doi:10.1186/2251-7715-1-15

Zucco MA, Walters SA, Chong S-K, Klubek BP, Masabn JG (2015) Effect of soil type and vermicompost applications on tomato growth. Int J Recycl Org Waste Agric 4:135-141. doi:10.1007/ s40093-015-0093-3 